University of Montana

ScholarWorks at University of Montana

$5-2-2011$

\title{
Climate Change Predicted to Shift Wolverine Distributions, Connectivity, and Dispersal Corridors
}

\author{
Kevin Scot McKelvey \\ The University of Montana \\ Jeffrey P. Copeland \\ Michael K. Schwartz \\ University of Montana - Missoula, mkschwartz@fs.fed.us \\ Jeremy S. Littell \\ Keith B. Aubry
}

See next page for additional authors

Follow this and additional works at: https://scholarworks.umt.edu/wildbio_pubs

Part of the Life Sciences Commons

Let us know how access to this document benefits you.

\section{Recommended Citation}

McKelvey, Kevin Scot; Copeland, Jeffrey P.; Schwartz, Michael K.; Littell, Jeremy S.; Aubry, Keith B.; Squires, John R.; Elsner, Marketa M.; and Mauger, Guillaume S., "Climate Change Predicted to Shift Wolverine Distributions, Connectivity, and Dispersal Corridors" (2011). Wildlife Biology Faculty Publications. 78. https://scholarworks.umt.edu/wildbio_pubs/78

This Article is brought to you for free and open access by the Wildlife Biology at ScholarWorks at University of Montana. It has been accepted for inclusion in Wildlife Biology Faculty Publications by an authorized administrator of ScholarWorks at University of Montana. For more information, please contact scholarworks@mso.umt.edu. 


\section{Authors}

Kevin Scot McKelvey, Jeffrey P. Copeland, Michael K. Schwartz, Jeremy S. Littell, Keith B. Aubry, John R. Squires, Marketa M. Elsner, and Guillaume S. Mauger 


\title{
Climate change predicted to shift wolverine distributions, connectivity, and dispersal corridors
}

\author{
Kevin S. McKelvey, ${ }^{1,5}$ Jeffrey P. Copeland, ${ }^{1}$ Michael K. Schwartz, ${ }^{1}$ Jeremy S. Littell, ${ }^{2}$ Keith B. Aubry, ${ }^{3}$ \\ John R. Squires, ${ }^{1}$ Sean A. Parks, ${ }^{4}$ Marketa M. Elsner, ${ }^{2}$ and Guillaume S. Mauger ${ }^{2}$ \\ ${ }^{1}$ USD A Forest Service, Rocky Mountain Research Station, 800 East Beckwith, Missoula, Montana 59801 USA \\ ${ }^{2}$ University of Washington Climate Impacts Group, 3737 Brooklyn Avenue NE, Seattle, Washington 98105 USA \\ ${ }^{3}$ USDA Forest Service, Pacific Northwest Research Station, 3625 93rd Avenue SW, Olympia, Washington 98512 USA \\ ${ }^{4}$ USDA Forest Service, Rocky Mountain Research Station, Aldo Leopold Wilderness Research Institute, 790 East Beckwith, \\ Missoula, Montana 59801 USA
}

\begin{abstract}
Boreal species sensitive to the timing and duration of snow cover are particularly vulnerable to global climate change. Recent work has shown a link between wolverine (Gulo gulo) habitat and persistent spring snow cover through 15 May, the approximate end of the wolverine's reproductive denning period. We modeled the distribution of snow cover within the Columbia, Upper Missouri, and Upper Colorado River Basins using a downscaled ensemble climate model. The ensemble model was based on the arithmetic mean of 10 global climate models (GCMs) that best fit historical climate trends and patterns within these three basins. Snow cover was estimated from resulting downscaled temperature and precipitation patterns using a hydrologic model. We bracketed our ensemble model predictions by analyzing warm (miroc 3.2) and cool (pcm1) downscaled GCMs. Because Moderate-Resolution Imaging Spectroradiometer (MODIS)-based snow cover relationships were analyzed at much finer grain than downscaled GCM output, we conducted a second analysis based on MODIS-based snow cover that persisted through 29 May, simulating the onset of spring two weeks earlier in the year. Based on the downscaled ensemble model, $67 \%$ of predicted spring snow cover will persist within the study area through 2030-2059, and 37\% through 2070-2099. Estimated snow cover for the ensemble model during the period 20702099 was similar to persistent MODIS snow cover through 29 May. Losses in snow cover were greatest at the southern periphery of the study area (Oregon, Utah, and New Mexico, USA) and least in British Columbia, Canada. Contiguous areas of spring snow cover become smaller and more isolated over time, but large $\left(>1000 \mathrm{~km}^{2}\right)$ contiguous areas of wolverine habitat are predicted to persist within the study area throughout the 21 st century for all projections. Areas that retain snow cover throughout the 21st century are British Columbia, north-central Washington, northwestern Montana, and the Greater Yellowstone Area. By the late 21st century, dispersal modeling indicates that habitat isolation at or above levels associated with genetic isolation of wolverine populations becomes widespread. Overall, we expect wolverine habitat to persist throughout the species range at least for the first half of the 21 st century, but populations will likely become smaller and more isolated.
\end{abstract}

Key words: climate change; corridor; downscale; ensemble model; fragmentation; Gulo gulo; habitat; hydrologic modeling; snow; wolverine.

\section{INTRODUCTION}

Boreal species that are adapted to cold, snowy environments are particularly susceptible to the impacts of predicted warming trends on snowpack. Not only do they display many specific adaptations to seasonal snow (e.g., enlarged feet and seasonally white pelage), but shifts in both temperature and precipitation are predicted to increase in magnitude toward the poles (IPCC 2007). Additionally, vast areas of boreal forest and tundra are relatively flat and will provide few higher elevation refuges should climates become unsuitable for

Manuscript received 16 November 2010; revised 2 May 2011; accepted 13 June 2011. Corresponding Editor: N. T. Hobbs.

${ }^{5}$ E-mail: kmckelvey@fs.fed.us boreal species (Loarie et al. 2009). For these reasons, the likelihood of boreal species persisting in montane areas at middle latitudes under global warming is of significant interest to conservation.

The wolverine (Gulo gulo) is a boreal species that may be particularly vulnerable to current trends in climatic warming (see Plate 1). It was once considered to be a habitat generalist whose geographic distribution was dictated more by the avoidance of humans than with specific habitat needs. However, recent research findings have substantially altered that perspective. Consistent with field observations indicating that all wolverine reproductive dens are located in areas that retain snow in the spring (Magoun and Copeland 1998), Aubry et al. (2007) concluded that the distribution of persistent 
spring snow cover was congruent with the wolverine's historical distribution in the contiguous United States. This relationship was further supported by the findings of Schwartz et al. (2007) that showed historical wolverine populations in the southern Sierra Nevada of California, which occupied a geographically isolated area of persistent spring snow cover, were genetically isolated from northern populations.

More recently, Copeland et al. (2010) compiled most of the extant spatial data on wolverine denning and habitat use to test the hypotheses that wolverines require snow cover for reproductive dens (Magoun and Copeland 1998), and that their geographic range is limited to areas with persistent spring snow cover (Aubry et al. 2007). Although Aubry et al.'s (2007) analysis covered only North America and used relatively coarse EASEGrid Weekly Snow Cover and Sea Ice Extent data (Armstrong and Brodzik 2005), Copeland et al. (2010) confirmed these relationships with finer scale snow data $(0.5-\mathrm{km}$ pixels) obtained throughout the Northern Hemisphere from the Moderate-Resolution Imaging Spectroradiometer (MODIS) instrument on the Terra satellite (Hall et al. 2006). Specifically, Copeland et al. (2010) compiled and evaluated the locations of 562 reproductive dens in North America and Scandinavia in relation to spring snow. All dens were located in snow and $97.9 \%$ were in areas identified as being persistently snow covered through the end of the wolverine's reproductive denning period (15 May; Aubry et al. 2007) based on MODIS imagery. Additionally, Copeland et al. (2010) found that areas characterized by persistent spring snow cover contained $89 \%$ of all telemetry locations from throughout the year in nine study areas at the southern extent of current wolverine range. Excluding areas where wolverines were known to have been extirpated recently, persistent spring snow cover provided a good fit to current understandings of the wolverine's circumboreal range (Copeland et al. 2010). Moreover, Schwartz et al. (2009) found that the genetic structure of wolverine populations in the Rocky Mountains was consistent with dispersal within areas identified as being snow covered in spring, and strong avoidance of other areas. Thus, the areas with spring snow cover that supported reproduction (Magoun and Copeland 1998) could also be used to predict year-round habitat use, dispersal pathways, and both historical (Aubry et al. 2007) and current ranges (Copeland et al. 2010).

The reasons that wolverines of both sexes remain in areas with persistent spring snow cover throughout the year is not well understood. Summer use of these areas may be due to avoidance of summer heat (Hornocker and Hash 1981, Copeland et al. 2010), prey availability in avalanche chutes and at timberline (Krebs et al. 2007), or perhaps a combination of both. Whatever the cause, evidence suggests that wolverines occurring at the southern periphery of their range remain within a relatively narrow elevation zone throughout the year
(Copeland et al. 2007). There is no evidence, either currently or historically, that wolverine populations can persist in other areas. For these reasons, Copeland et al. (2010) argued that the bioclimatic niche of the wolverine can be defined by the areal extent of persistent spring snow cover.

The wolverine was recently evaluated for listing under the Endangered Species Act of 1973 (16 U.S.C. 15311544, 87 Stat. 884) and received "Candidate" status in 2010 (USFWS 2010). If, as Copeland et al. (2010) and Aubry et al. (2007) argue, the extent of persistent spring snow cover has constrained current and historical distributions, then it is reasonable to assume that it will also constrain the wolverine's future distribution. Consequently, for conservation planning, predicting the future extent and distribution of persistent spring snow cover can help identify likely areas of range loss and persistence, and resulting patterns of connectivity.

\section{Regional snow modeling}

Choosing a global climate model.-To link future climate projections to current and historical patterns of wolverine habitat use requires modeling snow conditions into the future, and relating modeled snow to the MODIS-derived snow cover layer that Copeland et al. (2010) and Schwartz et al. (2009) correlated with patterns of wolverine habitat use and gene flow. Generally, future climatic conditions are estimated using global climate models (GCMs). There are $>20$ GCMs of varying structural complexity and greenhouse gas sensitivity, each of which can be forced with a variety of greenhouse gas emission scenarios. Recently, the Intergovernmental Panel on Climate Change (IPCC) argued that ensemble-averaging more faithfully reproduced existing patterns of climate change than any single model (IPCC 2007: Chapters 8 and 10). The IPCC used 23 GCMs, regardless of their bias or "skill levels" (IPCC 2007: Chapter 8). For finer scale regional modeling efforts, however, it may be more useful to generate an ensemble model based on the skill-weighted scenarios or subset of GCMs that best model historical trends for those regions (Macadam et al. 2010). For example, Mote and Salathé (2010) built a weighted composite model for the Pacific Northwest that emphasized those models that best fit local historical climate data.

Choosing an emission scenario.-Future climate will ultimately depend on future carbon emissions; accurate predictive modeling hinges on assumptions about future patterns of fossil fuel use. Unlike models that can be compared based on their abilities to simulate historical climate patterns, the likelihood of future emission scenarios is unknown. The IPCC developed a total of 40 emission scenarios (Special Report on Emissions Scenarios [SRES]; IPCC 2007, Nakicenovic et al. 2000), but only a few are widely used for simulation modeling: A2, representing heavy use of fossil fuels; A1B, reflecting a rapidly growing economy but with significant movement toward renewable power sources; and B1 or B2, 
which represent more conservative scenarios associated with organized efforts to reduce emissions worldwide. Although these scenarios result in highly divergent climatic conditions over the long term, they cluster tightly together in the short term; during the 21st century in the Pacific Northwest (PNW), model-tomodel variability greatly exceeds within-model differences due to different emission scenarios until at least the mid-21st century (Mote and Salathé 2010).

Downscaling.-Because GCMs are based primarily on mathematical models of the general circulation of the Earth's atmosphere, output grids are coarse in scale ( $\sim 100-300 \mathrm{~km}$, or 1-5 degrees latitude/longitude) and the underlying topography is greatly simplified. Processes such as the buildup of snowpack at higher elevations cannot be assessed at this scale. Therefore, if GCM output is to be used to simulate snowpack, results need to be downscaled. There are a variety of downscaling methods, but two primary approaches have been used: regional modeling, in which a finer grain circulation model is applied (GCMs provide boundary conditions; see Salathé et al. [2010] for an example in the Pacific Northwest), and statistical downscaling in which additional data such as topography and historical precipitation patterns are used to adjust GCM outputs to reflect local conditions (see Elsner et al. [2010] for an example in the Pacific Northwest). Fowler et al. (2007) provide a review of downscaling methods in the context of hydrological modeling which, in western North America, requires accurate estimation of snowpack.

Modeling snow.-Aubry et al. (2007), Schwartz et al. (2009), and Copeland et al. (2010) related wolverine habitat use and movements to persistent spring snow cover. For a pixel to be considered snow covered by Copeland et al. (2010), it had to be consistently covered with snow during a 21-day period ending on 15 May. The 21-day window had two purposes: It allowed cloudfree observation of each pixel, and it eliminated areas that were ephemerally snow covered but lacked residual snowpack. Although downscaled GCMs do not provide precise estimates that correspond to MODIS-based snow cover data, snowpack has been modeled by transforming downscaled GCM output using hydrologic models designed to work with interpolated weather station data. Wood et al. (2004) used the variable infiltration capacity (VIC) hydrologic model (Liang et al. 1994, Hamlet and Lettenmaier 2005) to test various downscaling approaches in the Pacific Northwest. VIC, which is designed to use interpolated weather data such as Historical Climate Network (e.g., Menne et al. 2010) or PRISM output (Daly et al. 1994, 2008), produces variables of hydrological interest including snow water equivalent (SWE) and snow depth.

In this paper, we modeled future patterns of persistent spring snow cover within the Columbia, Upper Colorado, and Upper Missouri River Basins using downscaled GCM temperature and precipitation data transformed into snow by the VIC hydrologic model.
Using understandings of the wolverine's bioclimatic niche derived by Copeland et al. (2010) we transformed these snow projections into predicted wolverine habitat and, using approaches developed by Schwartz et al. (2009), evaluated future changes in connectivity between areas of wolverine habitat.

\section{Methods \\ Ensemble model selection, downscaling, and hydrologic modeling}

We used a future climate projection derived from an ensemble mean of $10 \mathrm{GCMs}$ under a single intermediate emission scenario (A1B; Elsner et al. 2010, Littell et al. 2010, Mote and Salathé 2010) to produce climate projections in the Columbia, Upper Missouri, and Upper Colorado River Basins (Fig. 1). Starting with the IPCC Fourth Assessment Report's (AR4) suite of models (IPCC 2007), we eliminated models with poor cumulative performance or that routinely performed the worst in one or more categories, leaving an ensemble of the following $10 \mathrm{GCMs}$ : bccr, cnrm_cm3, csiro_3_5, echam5, echo_g, hadcm, hadgem1, miroc_3.2, miroc 3_2_hi, and pcm1 (Meehl et al. 2007, Littell et al. 2010).

We derived historical climate following methods in Hamlet and Lettenmaier (2005) as implemented for the Columbia River Basin by Elsner et al. (2010). We generated data sets similar to those used by Elsner et al. (2010) for the Upper Colorado and Missouri River Basins. We interpolated local climate from historical weather station data at 1/16 degree (latitude/longitude; $\sim 6 \mathrm{~km}$ at $45^{\circ} \mathrm{N}$ ) using PRISM (Daly et al. 1994, 2002; see Elsner et al. [2010] for details). We inferred future local climate patterns from each of the 10 GCMs by downscaling to this resolution using the "delta" method (e.g., Elsner et al. 2010), which assumes that local relationships, such as relative shifts in temperature and precipitation associated with elevation and prevalent weather patterns, remain constant. In the delta method, a GCM grid cell mean is fit to interpolated historical weather data. Projections are then forecast for a future period based on an expected emission scenario, and differences in cell values between the historical fit and the future projection are calculated. Downscaling is accomplished by adding these differences (deltas) to each cell in a fine-scale interpolated grid based on historical data, combined with topographic influences on temperature and precipitation. We averaged deltas derived from the $10 \mathrm{GCMs}$ to produce an ensemble model. From these data, we developed spatially explicit future temperature and precipitation deltas for each cell in the model grid for the years 2030-2059 and 20702099 under emission scenario A1B following methods similar to Elsner et al. (2010; see Littell et al. [2010] for details). In addition to the ensemble means, we produced similar climate surfaces for relatively cool ( $\mathrm{pcm} 1)$ and warm (miroc 3.2) models (based on evaluation of the Columbia and Upper Missouri domain; see Littell et al. [2010] for details) to produce a pseudo-range of 


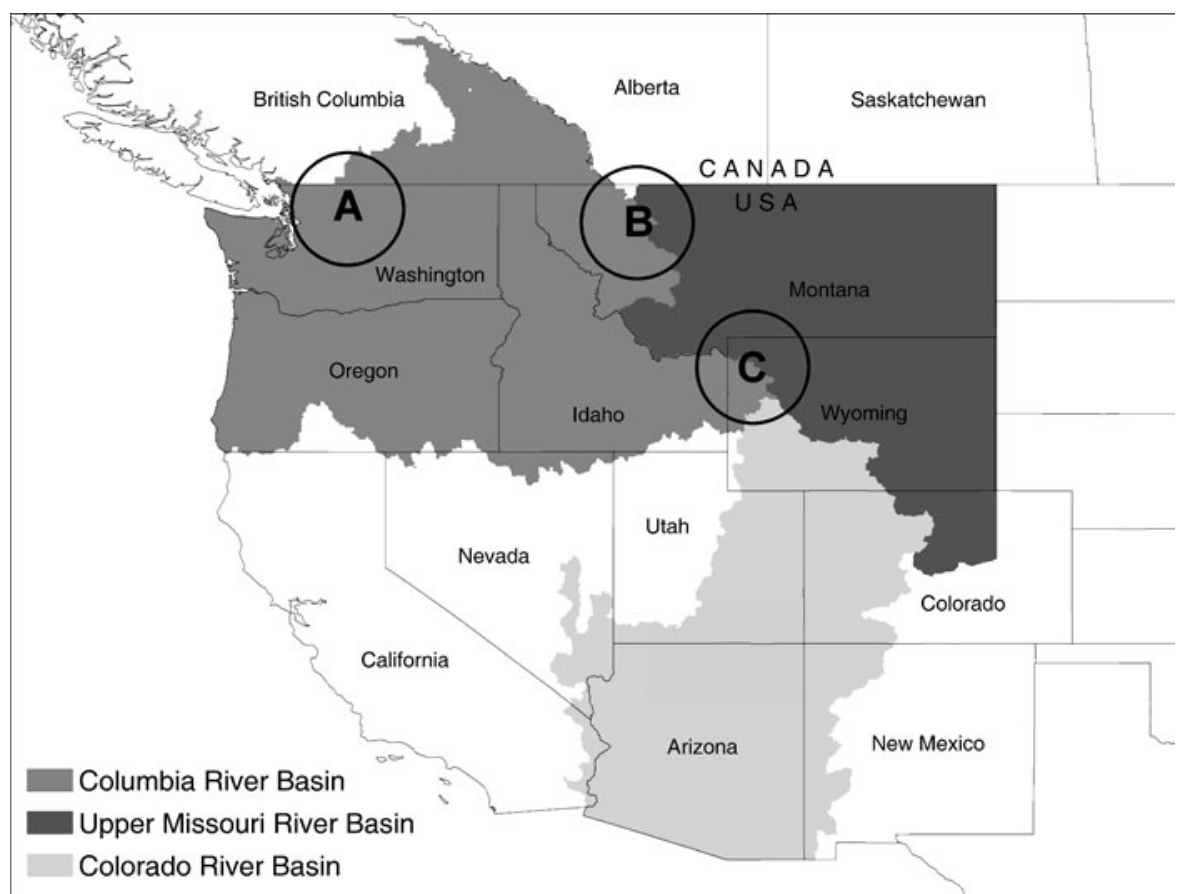

FIG. 1. The study area (shaded), including the Columbia, Upper Missouri, and Upper Colorado River Basins. Geographic or administrative areas referred to in the text include (A) the North Cascades in Washington and British Columbia, (B) Glacier National Park and Bob Marshall Wilderness in Montana, and (C) the Greater Yellowstone Area in Montana, Idaho, and Wyoming.

potential future climatic conditions. Following methods in Elsner et al. (2010), we used the 6-km regional precipitation and temperature estimates derived from the historical interpolated data, GCM ensemble, pcm1, and miroc 3.2 to drive a hydrologic model that we used to predict patterns of snow water equivalent (SWE) and snow depth.

Following Elsner et al. (2010), we used the VIC hydrologic model to transform temperature and precipitation into a suite of hydrological variables including snow depth and SWE. VIC is a validated and continuously maintained model that has been used widely in the Pacific Northwest to estimate snowpack volume, runoff, and streamflow (e.g., Elsner et al. 2010).

\section{Historical Reconstruction: cross-walking between downscaled GCM and MODIS}

Schwartz et al. (2009) and Copeland et al. (2010) used persistent snow cover through 15 May derived from daily $0.5-\mathrm{km}$ MODIS data to infer relationships between snow cover and wolverine denning, habitat use, and dispersal. Interpolated historical temperature and precipitation were input into VIC to model average snow depth and SWE for the 1st of each month at 1/16-degree resolution. Pixel-level correlations between modeled SWE and snow depth were $>99.5 \%$; we chose snow depth on 1May as the metric to match to MODISderived persistent spring snow cover. MODIS snow cover data were binary (snow covered or not); to convert VIC snow depth data to a binary cover variable, we established a threshold snow depth, whereby pixel values greater than the threshold were classified as snow covered. To produce the optimal fit, we searched for a threshold that maximized the agreement between MODIS 15 May snow cover and modeled snow depth, and minimized areas of disagreement. Because snow depth was evaluated for pixels $1 / 16$ degree in size, whereas MODIS data were at $0.5-\mathrm{km}$ resolution (about $140 \times$ as large), we resampled the VIC-generated snow depth to $0.5-\mathrm{km}$ scale while maintaining its alignment with the MODIS coverage. We then optimized the ratio of agreement to disagreement based on comparing the resampled coverage to MODIS-derived snow cover through 15 May (hereafter, the optimal fit between snow depth and MODIS snow cover is referred to as the Historical Reconstruction).

\section{Simulating the onset of spring snow melt two weeks earlier in the year}

To validate our GCM analysis, we conducted a second analysis looking at MODIS snow cover data later in the year. Many have argued that a variety of biological and physical attributes are occurring earlier in the year than they did in the early- to mid-20th century. Specifically, snow melt occurs earlier than it did 50-100 years ago (Mote et al. 2005, Knowles et al. 2006, Stewart 


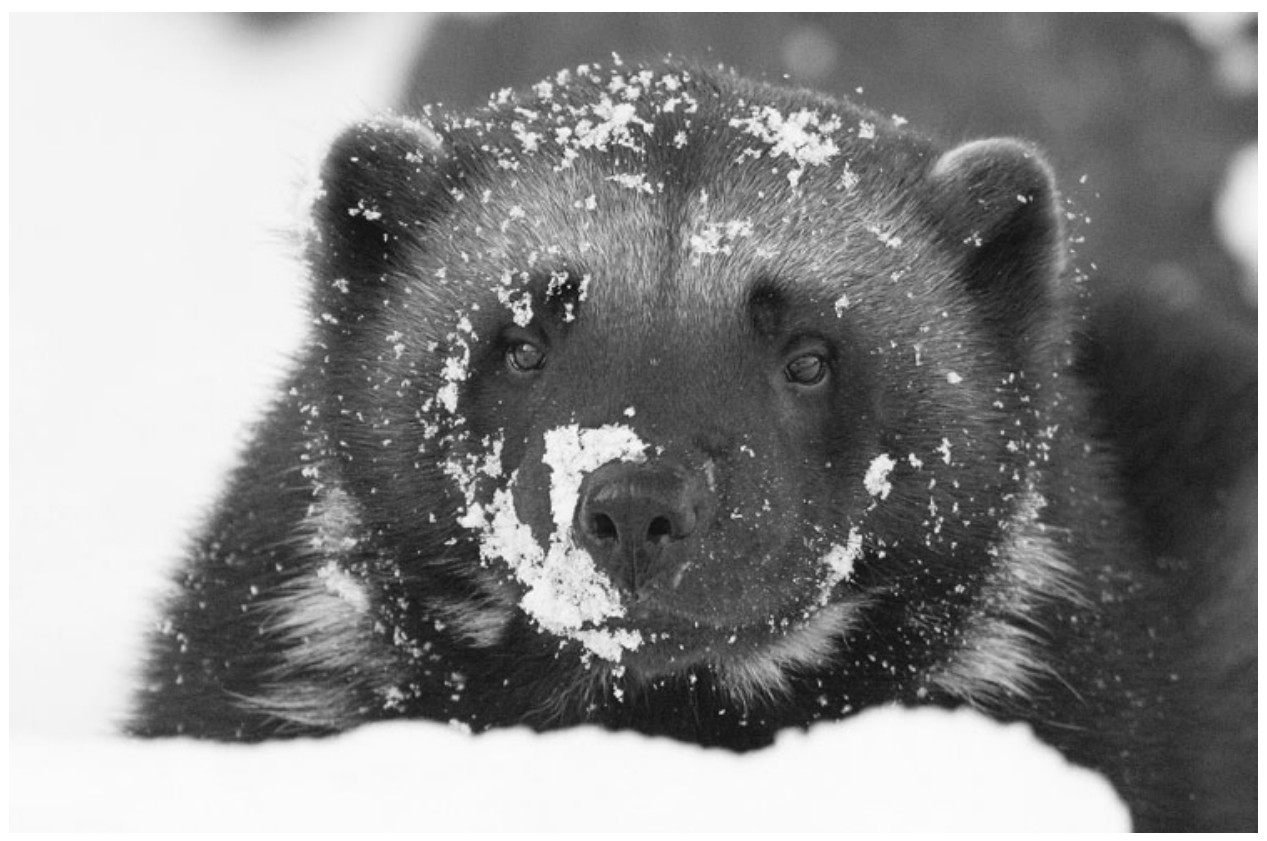

Plate 1. The wolverine (Gulo gulo), which is one of the largest terrestrial members of the weasel family, persists at extremely low population densities across alpine habitats of the Northern Hemisphere. The wolverine's obligate association with persistent snow cover for successful reproduction denning leaves the species vulnerable to decreasing habitat and population connectivity due to global warming. Photo credit: Dale Pedersen.

2009), consistent with the earlier onset of spring conditions. Based on plant and animal phenology, Menzel et al. (2006) estimated that the onset of spring/ summer has progressed at a rate of 2.5 days per decade. Consequently, we determined how wolverine distribution and connectivity would change if it were based on persistent snow cover through 29 May rather than 15 May, thereby forcing spring snow melt two weeks earlier. This approach does not account for changes in winter temperature and precipitation patterns (i.e., it does not predict future climates), but it is based on the same data as previous analyses of wolverine habitat use and dispersal (Schwartz et al. 2009, Copeland et al. 2010). Thus, errors associated with localizing and downscaling GCMs, transforming temperature and precipitation data into snow cover through VIC (Liang et al. 1994, Hamlet and Lettenmaier 2005), and crosswalking GCM-based snow depth to MODIS-based snow cover are eliminated.

\section{Predicting future snow cover and its influence on patterns} of wolverine habitat use and dispersal

Schwartz et al. (2009) used methods in which landscape features were transformed into putative movement costs that were used to derive matrices of least-cost paths among individuals. Associated costs were then correlated with matrices of genetic relatedness among individuals (Manel et al. 2003, Coulon et al. 2006, Cushman et al. 2006, 2009). Using these methods, genetic patterns best fit snow-covered landscapes when the costs associated with traveling within areas of snow cover were $1 / 20$ the costs of movements outside those areas. Schwartz et al. (2009) found that indications of genetic isolation in the Little Belt and Crazy Mountains in Montana correlated with higher movement costs to and from those areas. Because map boundaries differed, we repeated the analyses in Schwartz et al. (2009) and, assuming the same $1 / 20$ cost ratio for traveling within rather than outside snow-covered areas, applied these methods to the Historical Reconstruction. We used the average costs associated with the Little Belt and Crazy Mountains derived from MODIS-based snow cover through 15 May and the Historical Reconstruction to infer areas of genetic isolation associated with MODISbased snow cover through 29 May and GCM-based projections, respectively.

\section{Results}

\section{GCM model selection, downscaling, and performance}

Seven GCMs (bccr, echam5, echo_g, hadcm, hadgem1, miroc_3.2, and pcm1) performed consistently well in most metrics (e.g., annual precipitation and temperature trend) for all three river basins. The models fgoals1_0_g, gfdl_cm2_1, giss_aom, and ipsl_cm4 were less consistent across metrics and basins, and no models routinely performed best in all metrics. Other models (e.g., ccsm3, both $\mathrm{cgcm}$ models, giss_er) performed well in some indicators (e.g., average annual precipitation) and not in others (e.g., $20^{\text {th }}$-century trend in temperature). For example, giss_er performed well in all categories except the North Pacific index, for which it ranks lowest of all 
TABLE 1. Confusion matrix for cross-walk between persistent spring snow cover based on $0.5-\mathrm{km}$ Moderate Resolution Imaging Spectroradiometer (MODIS) data (Copeland et al. 2010) and historical 1 May snow depth based on 1/16-degree (latitude/longitude) resolution variable infiltration capacity (VIC) hydrologic modeling (Historical Reconstruction).

\begin{tabular}{lrr}
\hline \hline & \multicolumn{2}{c}{ MODIS } \\
\cline { 2 - 3 } & \multicolumn{1}{c}{ Snow } & No snow \\
\hline Historical Reconstruction & & \\
Snow & 1160771 & 503389 \\
No snow & 222488 & 9655150 \\
\hline
\end{tabular}

Note: The 1/16-degree pixels were rescaled to match the 0.5 $\mathrm{km}$ MODIS data, and numbers in the cells indicate the number of $0.5 \times 0.5 \mathrm{~km}$ areas where the projections agreed or disagreed.

models (Mote and Salathé 2010). For each model, regional rankings are relatively consistent among the three river basins (see Littell et al. [2010] for details).

Based on the ensemble projections, increases in average annual temperature for 2030-2059 are predicted for all three river basins: $+2.1^{\circ} \mathrm{C}$ for the Columbia Basin $\left(\mathrm{pcm} 1,+1.8^{\circ} \mathrm{C}\right.$; and miroc $\left.3.2,+2.7^{\circ} \mathrm{C}\right),+2.3^{\circ} \mathrm{C}$ for the Upper Missouri Basin $\left(\mathrm{pcm} 1,+1.7^{\circ} \mathrm{C}\right.$; and miroc 3.2, $+3.1^{\circ} \mathrm{C}$ ), and $+2.4^{\circ} \mathrm{C}$ for the Upper Colorado Basin $\left(\mathrm{pcm} 1,+1.7^{\circ} \mathrm{C}\right.$; and miroc $\left.3.2,+3.3^{\circ} \mathrm{C}\right)$, with $0 \%, 3 \%$, and $2 \%$ increases in annual precipitation, respectively. For $2070-2099$, predicted increases are $+3.8^{\circ} \mathrm{C}$ for the Columbia Basin $\left(\mathrm{pcm} 1,+2.7^{\circ} \mathrm{C}\right.$; and miroc $\left.3.2,+4.6^{\circ} \mathrm{C}\right)$, $+4.1^{\circ} \mathrm{C}$ for the Upper Missouri Basin $\left(\mathrm{pcm} 1,+2.6^{\circ} \mathrm{C}\right.$; and miroc $3.2,+5.3^{\circ} \mathrm{C}$ ), and $+4.3^{\circ} \mathrm{C}$ for the Upper Colorado Basin $\left(\mathrm{pcm} 1,+2.6^{\circ} \mathrm{C}\right.$; and miroc $\left.3.2,+5.7^{\circ} \mathrm{C}\right)$, with $2 \%, 7 \%$, and $5 \%$ increases in annual precipitation, respectively. The variation in precipitation among GCMs in the ensemble is large and differs among regions and seasons, but predictions for the ensemble mean winter (December/January/February) precipitation increase in all three basins (4-8\% for 2030-2059; 9-
13\% for 2070-2099). However, in the spring (March/ April/May), precipitation increases in the Columbia (4\% for 2030-2059; 7\% for 2070-2099) and Upper Missouri (5\% in 2030-2059; $11 \%$ for 2070-2099) Basins, but decreases in the Upper Colorado Basin ( $-4 \%$ for 2030 $2059 ;-7 \%$ for $2070-2099$ ).

\section{Cross-walk between MODIS and the ensemble climate model}

The best fit between snow depth based on the Historical Reconstruction and the MODIS-based snow cover layer through 15 May (hereafter, 15 May MODIS) occurred when 1/16-degree pixels with average snow depth values $>13 \mathrm{~cm}$ were considered snow covered and those with $<13 \mathrm{~cm}$ were not. Rescaling the 1/16-degree map to $0.5-\mathrm{km}$ pixels to match the MODIS data resulted in the correct classification of $93.7 \%$ of pixels (Table 1). Spatial patterns were also similar (Fig. 2). Because fitting was done by maximizing the ratio of correctly classified snow pixels to misclassifications, more snow cover was generated in the Historical Reconstruction than in 15 May MODIS (Table 2). Most of the additional areas classified as snow covered in the Historical Reconstruction were in the Columbia River Basin (Table 2, Fig. 2A). Some areas, such as the northern Cascade Range in Washington and British Columbia, had more snow area in the Historical Reconstruction. Overall, the Upper Missouri and Upper Colorado River Basins contained slightly less snowcovered area in the Historical Reconstruction than in 15 May MODIS.

\section{Future predictions based on ensemble means}

Spring snow cover projections based on the ensemble mean climate for 2030-2059 (hereafter, Ensemble 2045) retained $66.8 \%$ of spring snow cover depicted in the Historical Reconstruction (Table 2). Predicted losses in

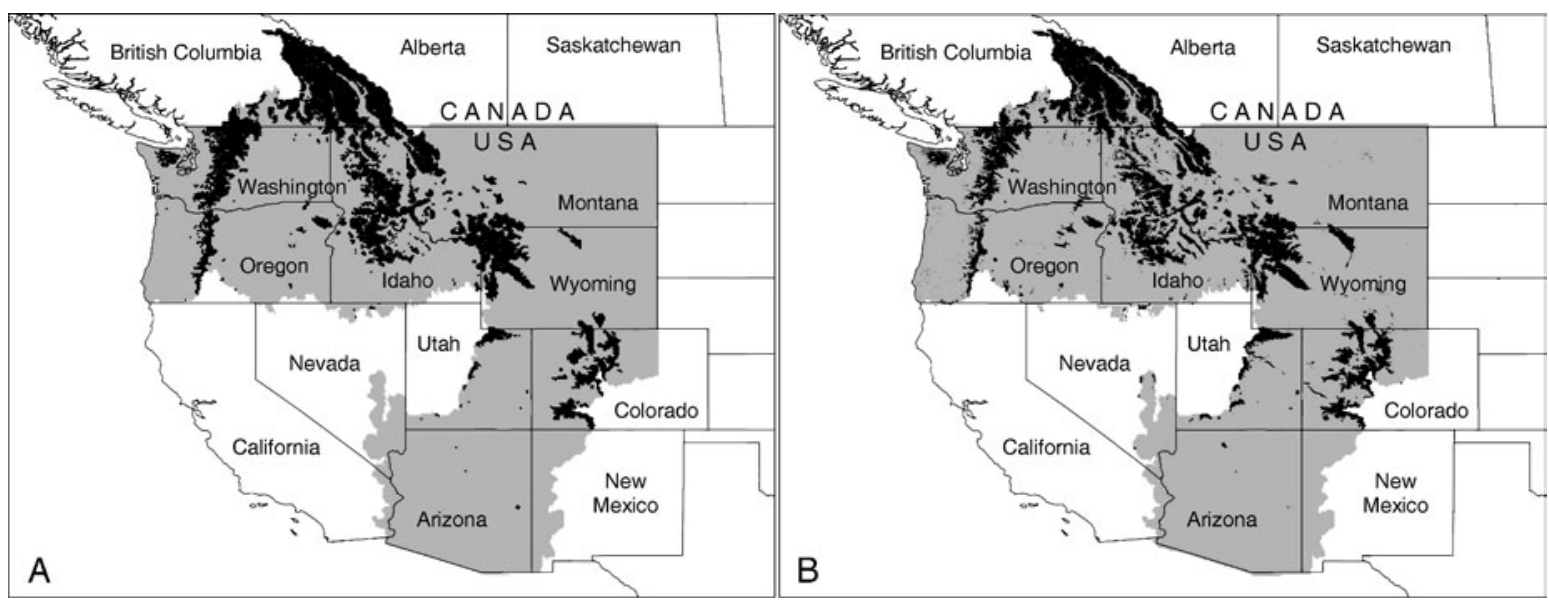

FIG. 2. Comparison between the (A) 1/16-degree Historical Reconstruction of snow cover and (B) Moderate Resolution Imaging Spectroradiometer (MODIS)-based snow cover through 15 May (Copeland et al. 2010). The study area is shown in gray, and snow cover is black. Historical Reconstruction refers to the optimal fit between snow depth and MODIS snow cover. In the Historical Reconstruction, we classified 1/16-degree pixels as wolverine habitat if snow depth exceeded $13 \mathrm{~cm}$. 
TABLE 2. Areal extent of persistent spring snow cover in river basins, states, and provinces analyzed using MODIS and three downscaled climate projections (Ensemble, miroc 3.2, and pcm1).

\begin{tabular}{|c|c|c|c|c|c|c|c|}
\hline \multirow[b]{2}{*}{ Location } & \multicolumn{7}{|c|}{ Snow cover, by model type $\left(\mathrm{km}^{2}\right)$} \\
\hline & $\begin{array}{l}15 \text { May } \\
\text { MODIS }\end{array}$ & $\begin{array}{l}29 \text { May } \\
\text { MODIS }\end{array}$ & $\begin{array}{c}\text { Historical } \\
\text { Reconstruction }\end{array}$ & $\begin{array}{c}\text { Ensemble } \\
2045\end{array}$ & $\begin{array}{c}\text { Ensemble } \\
2085\end{array}$ & $\begin{array}{l}\text { miroc } 3.2 \\
2070-2099\end{array}$ & $\begin{array}{c}\text { pcm 1, } \\
2070-2099\end{array}$ \\
\hline \multicolumn{8}{|l|}{ River basin } \\
\hline Columbia & 92332 & 40285 & 127302 & 83237 & 43211 & 17311 & 50672 \\
\hline Upper Missouri & 42601 & 16996 & 40484 & 30814 & 19837 & 7566 & 26660 \\
\hline Upper Colorado & 32334 & 8681 & 30029 & 18240 & 10364 & 2285 & 12619 \\
\hline Total & 167268 & 65962 & 197815 & 132290 & 73411 & 27163 & 89952 \\
\hline \multicolumn{8}{|l|}{ State/province } \\
\hline British Columbia & 60176 & 43081 & 76263 & 67382 & 57831 & 48725 & 59026 \\
\hline Washington & 21883 & 12214 & 33891 & 24594 & 14744 & 10326 & 16933 \\
\hline Oregon & 10122 & 2660 & 12716 & 6281 & 2589 & 1417 & 3949 \\
\hline Idaho & 35206 & 12919 & 44769 & 25724 & 9977 & 1433 & 13928 \\
\hline Montana & 35727 & 16490 & 45914 & 33506 & 20163 & 6937 & 23431 \\
\hline Wyoming & 31588 & 14005 & 31264 & 23556 & 14437 & 3995 & 17570 \\
\hline Nevada & 1000 & 27 & 288 & 72 & 0 & 0 & 0 \\
\hline Utah & 9588 & 2476 & 5820 & 2956 & 1438 & 0 & 1586 \\
\hline Colorado & 27702 & 6681 & 27409 & 18525 & 11756 & 3203 & 14506 \\
\hline New Mexico & 261 & 1 & 281 & 40 & 0 & 0 & 40 \\
\hline Total $\dagger$ & 173077 & 67472 & 202353 & 135253 & 75104 & 27310 & 91941 \\
\hline
\end{tabular}

Notes: Ensemble 2045 and Ensemble 2085 refer to snow cover projections based on downscaled ensemble global climate modeling (GCM) for the periods 2030-2059 and 2070-2099, respectively. Models pcm1 and miroc 3.2 refer to snow cover projections for the period 2070-2099 based on downscaling of the National Center for Atmospheric Research (NCAR)'s Parallel Climate Model and the medium resolution Model for Interdisciplinary Research on Climate collectively created by the Center for Climate System Research (University of Tokyo), National Institute for Environmental Studies, and Frontier Research Center for Global Change, Japan (see Littell et al. [2011] for details).

$\dagger$ Totals for the state/province analysis vary slightly from those for the basins because the basin polygons clip the edges of pixels that are not clipped by state boundaries; therefore, the state/province totals always are slightly larger than those for the basins.

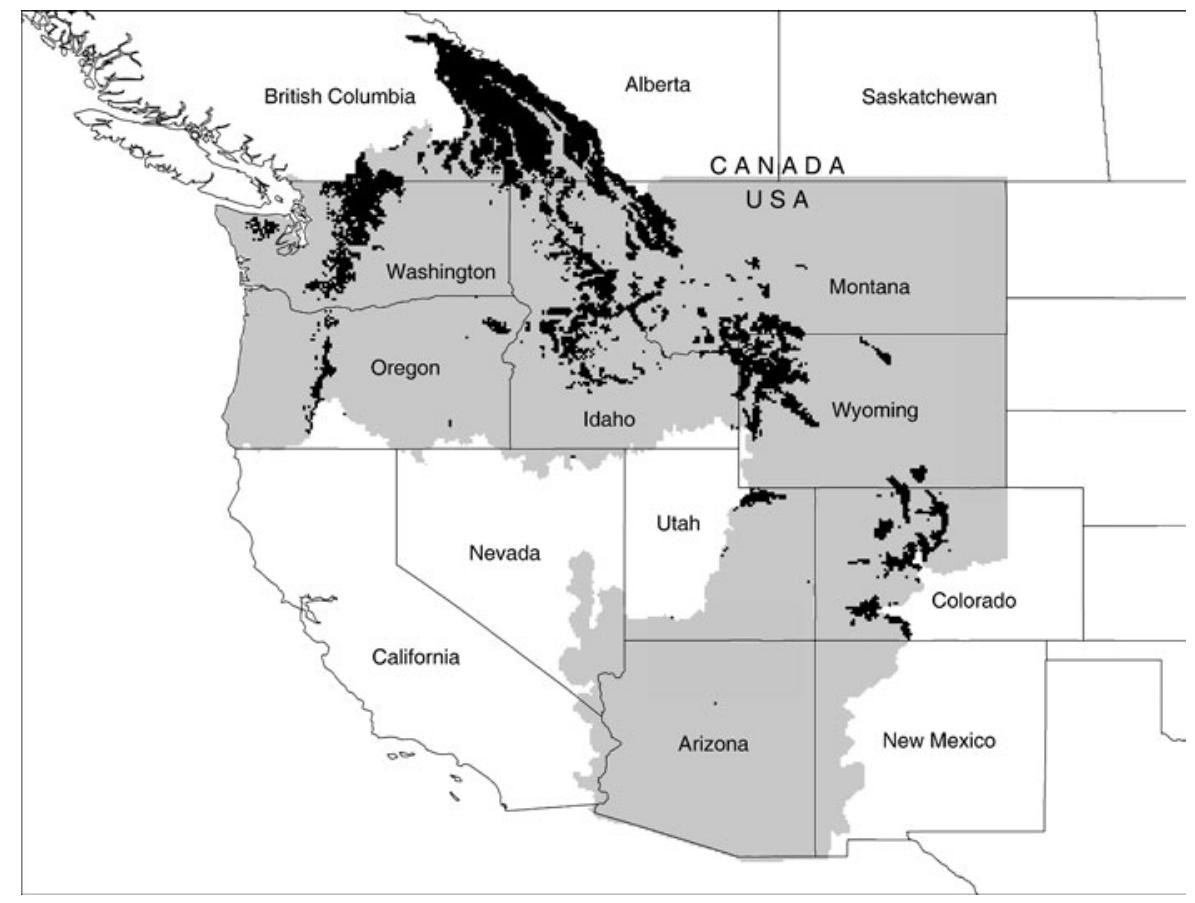

FIG. 3. Ensemble model projections for the period 2030-2059 (Ensemble 2045). Ensemble 2045 refers to snow cover projections based on downscaled ensemble global climate models (GCM) and hydrologic modeling for the period 2030-2059. The study area is shown in gray, and snow cover is black. 

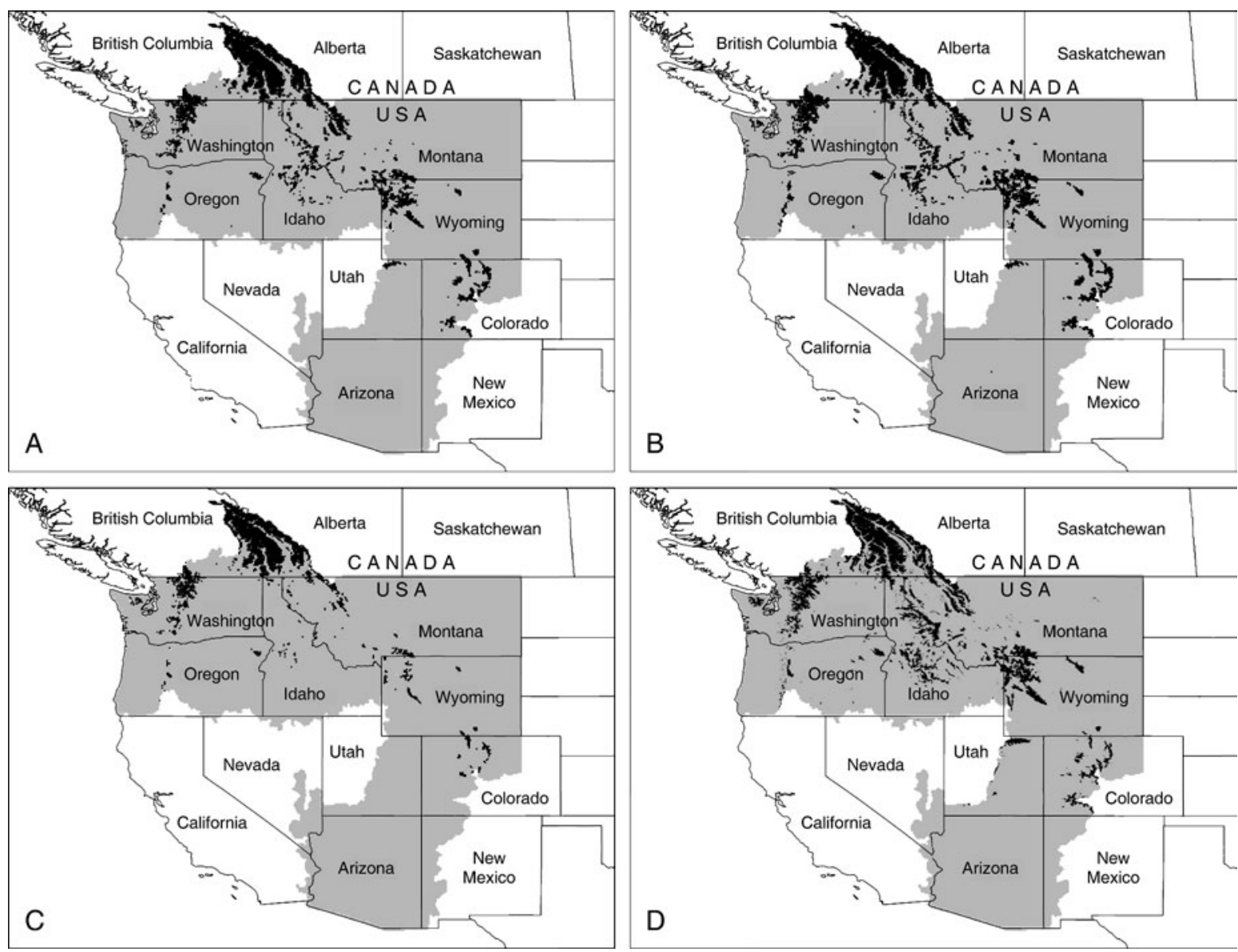

FIG. 4. Comparisons among three model projections, (A) Ensemble, (B) pcm1, and (C) miroc 3.2 for the period 2070-2099, and (D) MODIS-based snow cover through 29 May. Ensemble 2045 and Ensemble 2085 refer to snow cover projections based on downscaled ensemble GCM and hydrologic modeling for the periods 2030-2059 and 2070-2099, respectively. Models pcm1 and miroc 3.2 refer to snow cover projections for the period 2070-2099 based on downscaling of the National Center for Atmospheric Research's Parallel Climate Model and the medium resolution Model for Interdisciplinary Research on Climate collectively created by the Center for Climate System Research (University of Tokyo), National Institute for Environmental Studies, and Frontier Research Center for Global Change, Japan (see Littell et al. [2011] for details). The study area is shown in gray, and snow cover is black.

snow-covered areas were greatest at the southern periphery of our study area; i.e., New Mexico, Nevada, and Oregon will lose most (50.6-85.9\%) of their spring snow cover, whereas Idaho is predicted to lose only $42.5 \%$ of its current snow cover. Losses were smallest in those areas currently characterized by extensive areas of spring snow cover: British Columbia, the northern Cascade Range in Washington, Glacier National Park and Bob Marshall Wilderness in western Montana, and the Greater Yellowstone Area in Montana, Idaho, and Wyoming (Figs. 1 and 3).

Spring snow cover projections based on ensemble mean climate for 2070-2099 (hereafter, Ensemble 2085) show continued declines in spring snow cover across the study area, with only $37.1 \%$ of spring snow cover remaining overall (Table 2). Only British Columbia retains most of its spring snow cover $(75.8 \%)$. The states of Washington, Montana, Wyoming, and Colorado all retain $>40 \%$ of their snow cover. Oregon, Idaho, and Utah lose $75.3-79.6 \%$ of their spring snow cover. Snow cover is eliminated in those portions of Nevada and New Mexico that are included in the Columbia and Upper Colorado River Basins (Table 2, Fig. 4A).

\section{May MODIS}

MODIS-based persistent snow cover through 29 May (hereafter, 29 May MODIS) retained 39.0\% of snowcovered areas compared to 15 May MODIS (Table 2). By 29 May, large declines in snow cover are predicted in central Idaho, but snow cover is largely retained in British Columbia. Both the Glacier National Park/Bob Marshall Wilderness and the Greater Yellowstone Area maintain spring snow cover, but become more fragmented (Figs. 1 and 4D). 


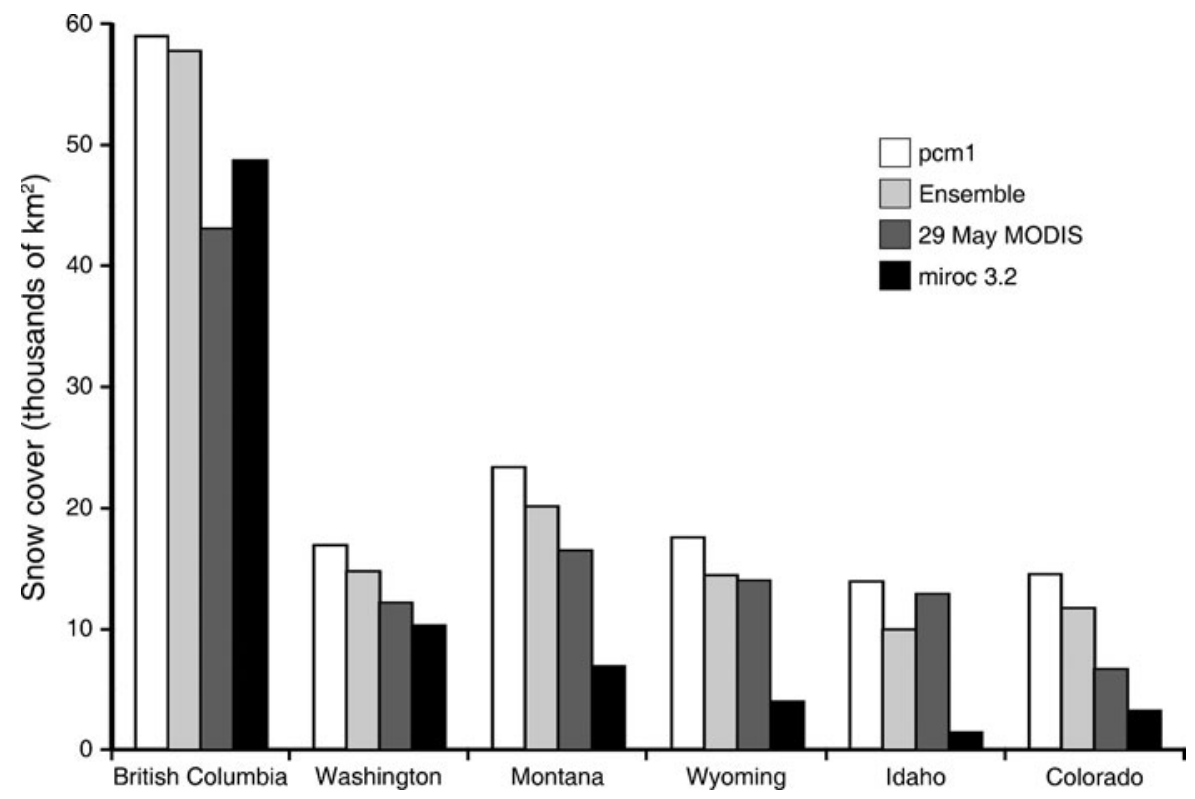

FIG. 5. Comparisons of the areal extent of persistent spring snow cover among three downscaled climate models (pcml, Ensemble, miroc 3.2) and MODIS data extending the snow-cover period through 29 May. All model projections are for the period 2070-2099.

Comparisons between GCM projections for 2070-2099 and 29 May MODIS

Of the three alternative GCM projections (ensemble, miroc 3.2, and pcm1), spring snow cover in 29 May MODIS is most similar to Ensemble 2085 projections (Table 2, compare Fig. 4A with Fig. 4D). As expected, by $2070-2099$, pcm 1 has the most spring snow cover and miroc 3.2 has the least. Of the three alternative projections, Ensemble 2085 is most divergent from miroc 3.2 (compare Fig. 4A with Fig. 4C). In terms of spatial patterns, Ensemble 2085 is most consistent with pcm1, but in most areas, pcm1 results in slightly more snow cover (Fig. 5, Table 2). Models are most convergent in British Columbia (Fig. 6), where most

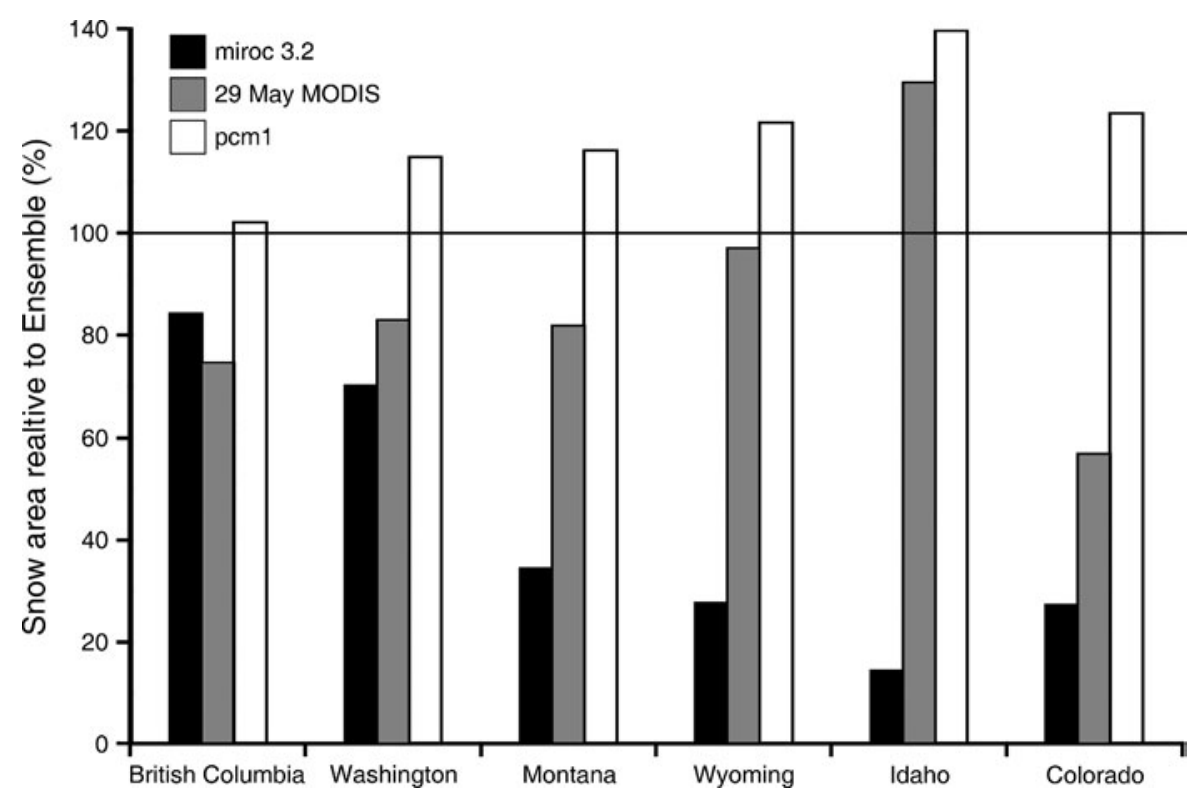

FIG. 6. Comparison of spring snow distributions between the ensemble-averaged GCM projection (Ensemble 2085), the cool ( $\mathrm{pcm} 1$ ), and warm (miroc 3.2) projections, and MODIS snow cover extended through 29 May. All model projections are for the period 2070-2099. 


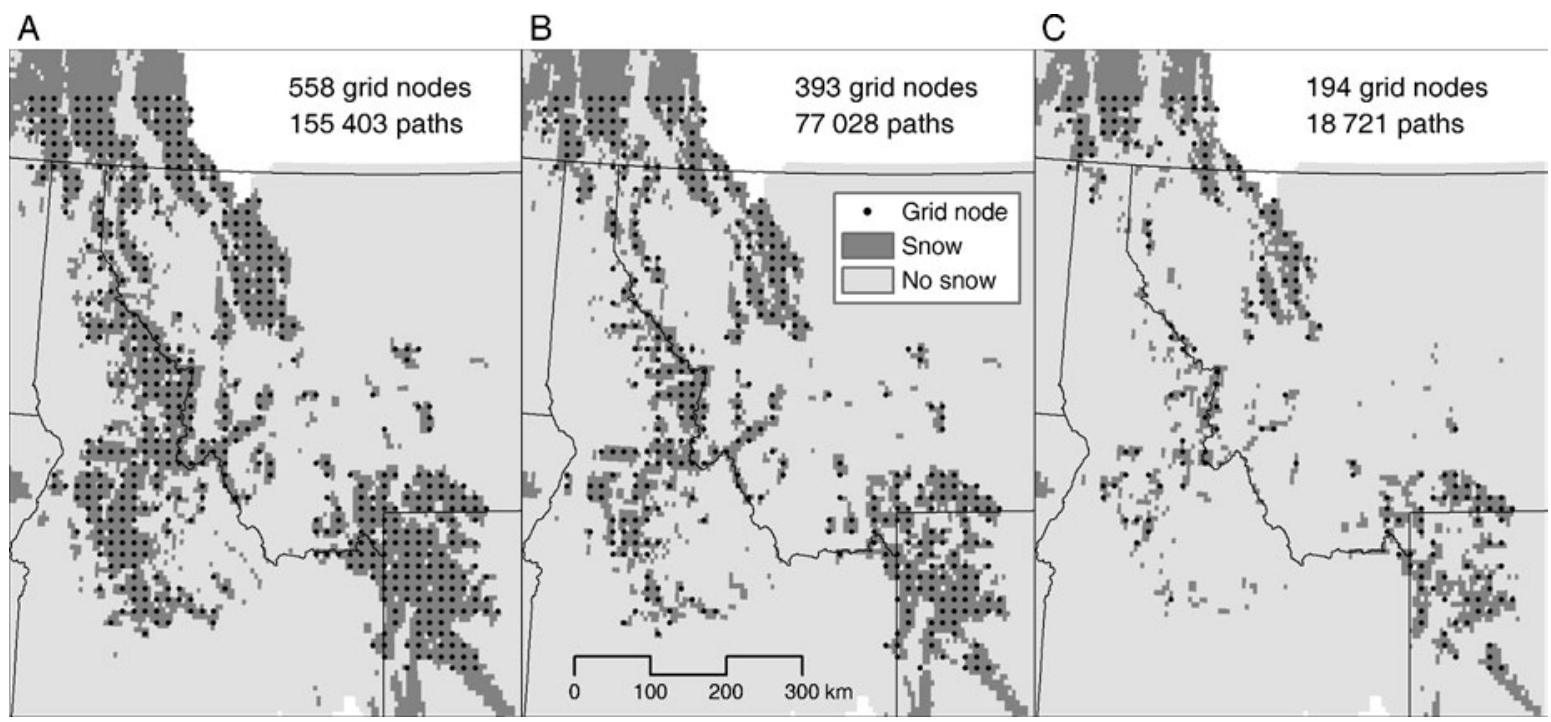

FIG. 7. Source and destination "grid nodes" for each period of analysis: the (A) Historical Reconstruction, and ensemble projections for (B) the periods 2030-2059 (Ensemble 2045) and (C) for 2070-2099 (Ensemble 2085). We located snow points by placing points at $15-\mathrm{km}$ intervals and keeping only those points that overlapped with a snowpack patch at least $225 \mathrm{~km}^{2}$ in size (see Schwarz et al. [2009] for details). "Paths" refer to the total number of pairwise least-cost paths possible given the number of nodes.

spring snow cover is retained in all projections (Table 2), and most divergent in Idaho, which is the only area where 29 May MODIS shows more snow-covered areas than Ensemble 2085 (Fig. 6).

\section{Modeling the future connectivity of wolverine populations}

Ensemble projections.-Each point where a wolverine could originate requires a contiguous snow area larger than $15 \times 15 \mathrm{~km}\left(225 \mathrm{~km}^{2}\right)$, which is the approximate home range size for female wolverines (Schwartz et al.
2009). Thus, the number of potential pairwise paths drops quadratically as snow-covered areas $>225 \mathrm{~km}^{2}$ in size are lost. The number of potential start locations decreases from 558 in the Historical Reconstruction to 194 in Ensemble 2085 and this decrease, in turn, leads to an order-of-magnitude reduction in the number of pairwise least-cost paths (Fig. 7). Due to the loss of spring snow cover in Idaho (Table 2) predicted by Ensemble 2085, the most important corridors connecting Glacier National Park and the Bob Marshall

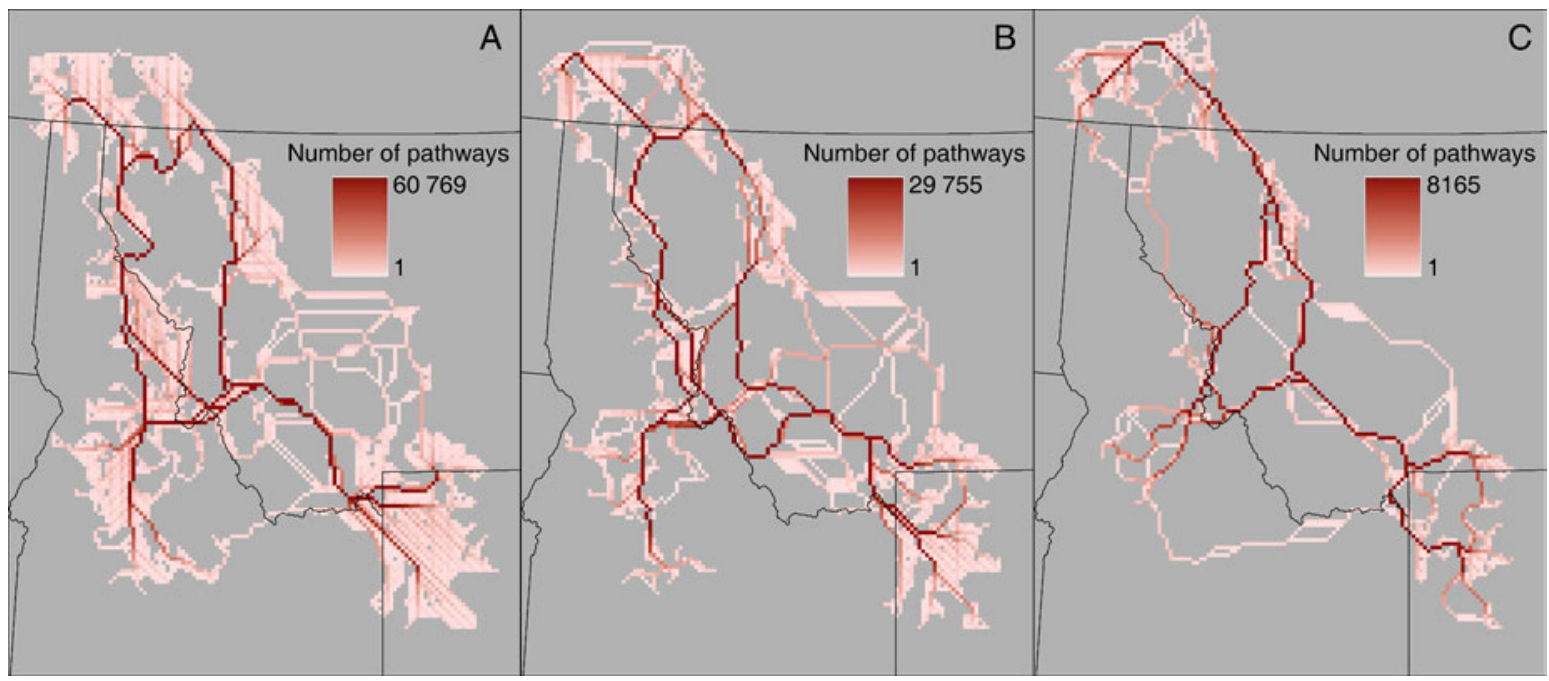

FIG. 8. Cumulative cost paths for all pairs of snow points for the (A) Historical Reconstruction, and ensemble projections for (B) the periods 2030-2059 (Ensemble 2045) and (C) 2070-2099 (Ensemble 2085). Coloring has been scaled to the total number of pairwise least-cost paths that cross each pixel (see Schwartz et al. [2009] for details), which declines over time due to decreased habitat. 

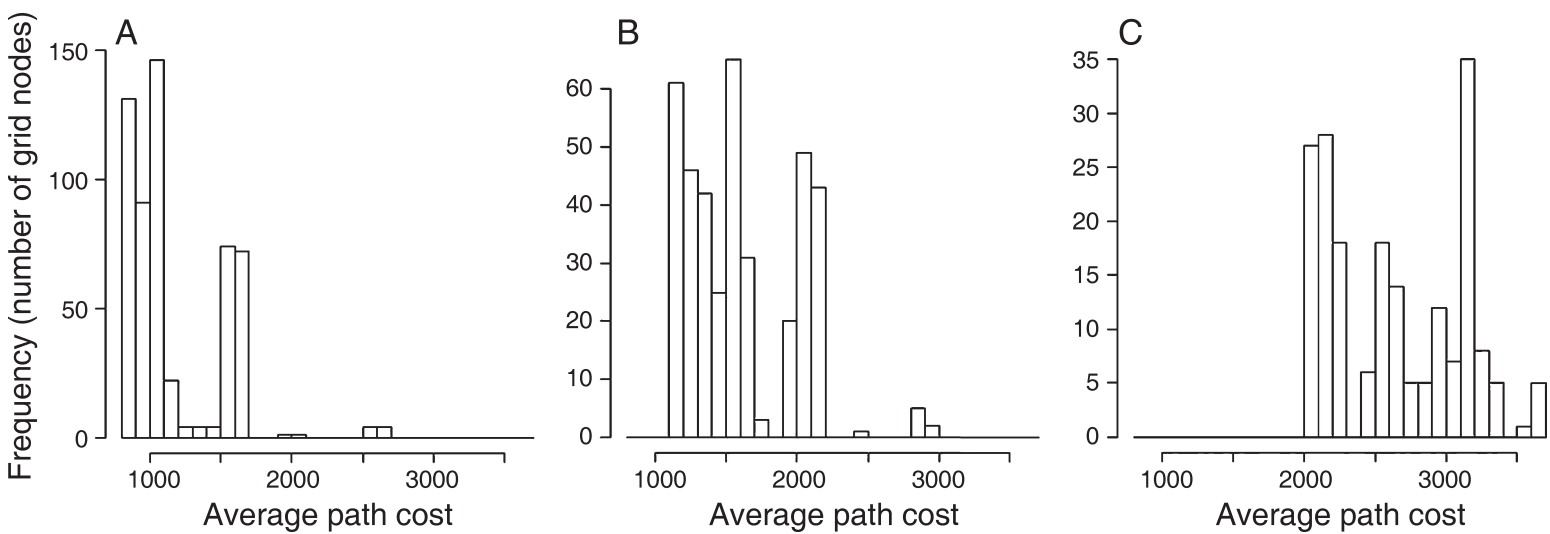

FIG. 9. Frequency distribution depicting the average path cost from each snow point to all other snow points for the (A) Historical Reconstruction, and ensemble projections for (B) the period 2030-2059 (Ensemble 2045) and (C) for 2070-2099 (Ensemble 2085). The average path cost units are arbitrary and are computed as the sum costs associated with all pairwise least-cost paths between a given node and all other nodes divided by the total number of paths.

Wilderness to the Greater Yellowstone Area shift eastward, favoring more direct north-south connections (compare Fig. 8A with Fig. 8C). With the decline in snow-covered area, average movement cost between locations increases (Fig. 9). Movement cost values at or higher than those associated with currently observed genetic isolation (Schwartz et al. 2009) occur between all locations based on Ensemble 2085 predictions (Figs. 9 and 10).

29 May MODIS.-Because 29 May MODIS is based on the same data source and therefore is at the same resolution as the analyses conducted by Schwartz et al. (2009), connectivity maps generated by Schwartz et al. (2009) can be directly compared with those in 29 May MODIS (Fig. 11). Comparing spring snow cover in 29
May MODIS with that in 15 May MODIS, western pathways become less important and direct north-south connections more so, but the shift is not as dramatic as in connectivity maps for Ensemble 2085 (compare Figs. 8 and 11). Increases in average movement cost when comparing 29 May MODIS least-cost paths with those in 15 May MODIS (Fig. 12; Schwartz et al. 2009) suggest changes in connectivity similar to those predicted in Ensemble 2085 (compare Figs. 9 and 12), in which average movement costs associated with genetic isolation become widespread.

\section{DisCUSSION}

The ensemble of $10 \mathrm{GCMs}$ selected for our analyses produced mean annual and seasonal projections that

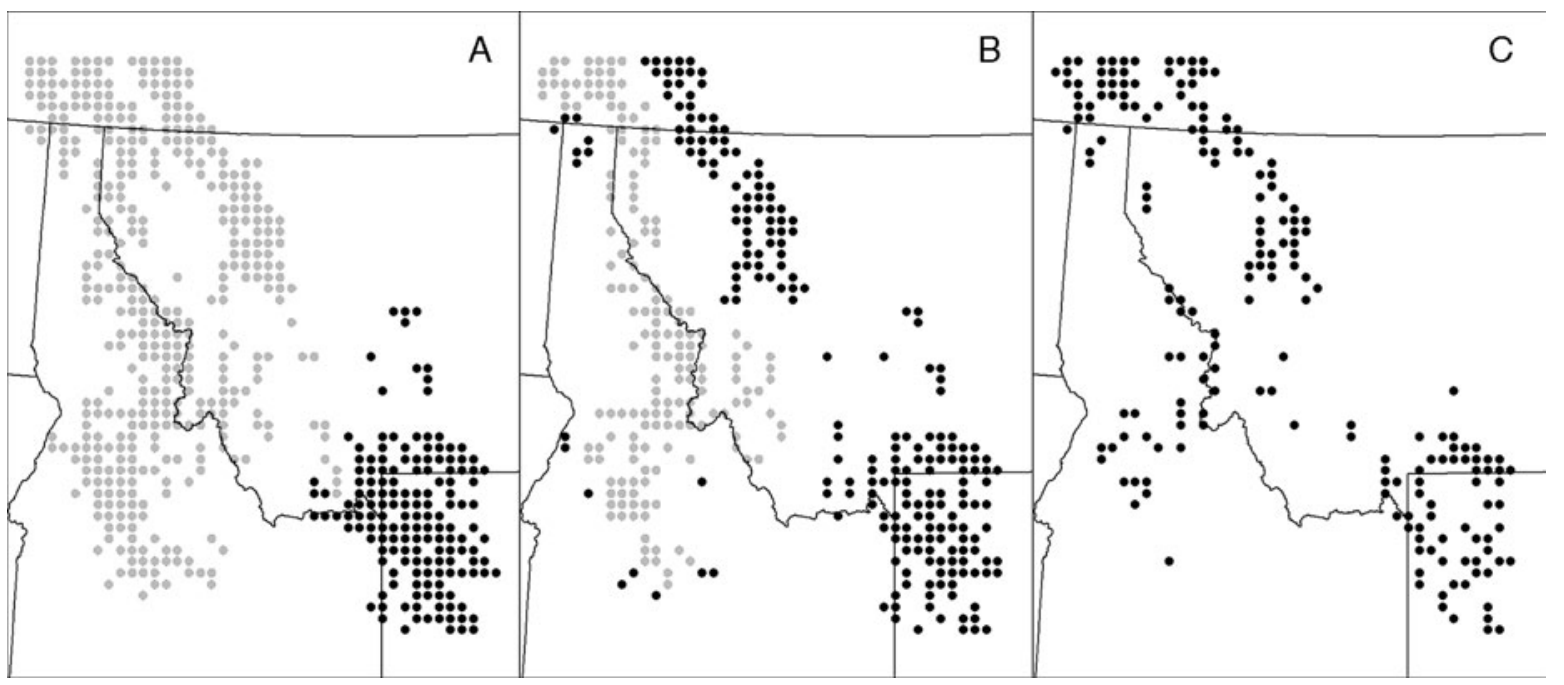

FIG. 10. Maps depicting whether snow points in the northern Rocky Mountains were genetically isolated (black circles) or not (gray circles), based on least-cost connectivity pathways and thresholds of isolation developed by Schwartz et al. (2009). (A) Current patterns of genetic isolation (Schwartz et al. 2009) are compared with predicted patterns of isolation for (B) the periods 2030-2059 (Ensemble 2045) and (C) for 2070-2099 (Ensemble 2085). 


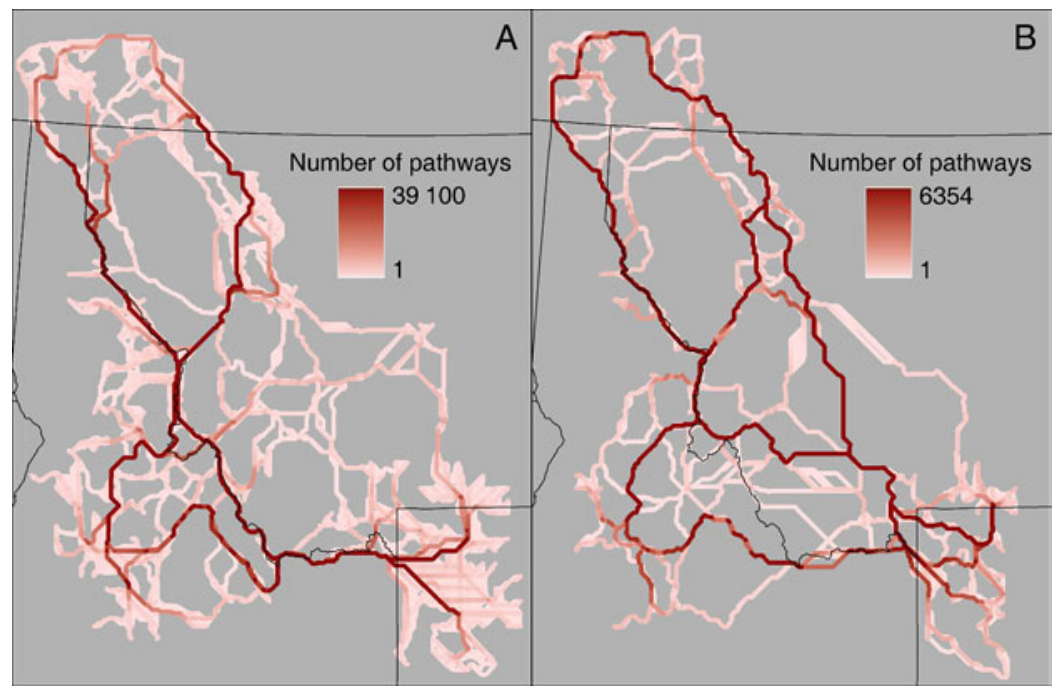

FIG. 11. Wolverine connectivity pathways based on (A) persistent snow cover through 15 May and (B) persistent snow cover through 29 May. Panel (A) is similar to Fig. 4 in Schwartz et al. (2009) and shows putative wolverine paths based on conformity with observed patterns of genetic structure. Panel (B) uses the same model to predict wolverine paths with an additional two weeks of snowmelt. Coloring has been scaled to the total number of pairwise least-cost paths that cross each pixel (see Schwartz et al. [2009] for details), which declines over time due to decreased habitat.

generally agree with the ensemble of 20 GCMs using the A1B emission scenario analyzed by Mote and Salathé (2010) for the Pacific Northwest. However, there are regional differences in the projections: Slightly more warming is predicted in the Upper Colorado River Basin than in the Upper Missouri Basin, which in turn, is slightly greater than in the Columbia Basin. The Pacific Northwest is characterized by large amounts of winter precipitation at temperatures near freezing. Thus, modest increases in temperature cause precipitation to fall as rain rather than snow, making its snowpack highly vulnerable to climatic warming (e.g., Elsner et al.
2010, Mantua et al. 2010). However, perhaps because historical snowpack is so deep and extensive in the Pacific Northwest, estimated May snow cover in that region is not as highly impacted by climate change as are interior areas, such as Idaho (Table 2).

Given a warming trend, spring snow cover is expected to decline and snow-covered areas are expected to become more fragmented and isolated. However, the ensemble model was more consistent with $\mathrm{pcm} 1$ (the cool extreme of the applied models) than with miroc 3.2 (the warmest model). For this reason, most snow cover $(66.9 \%)$ is retained in Ensemble 2045. Additionally,
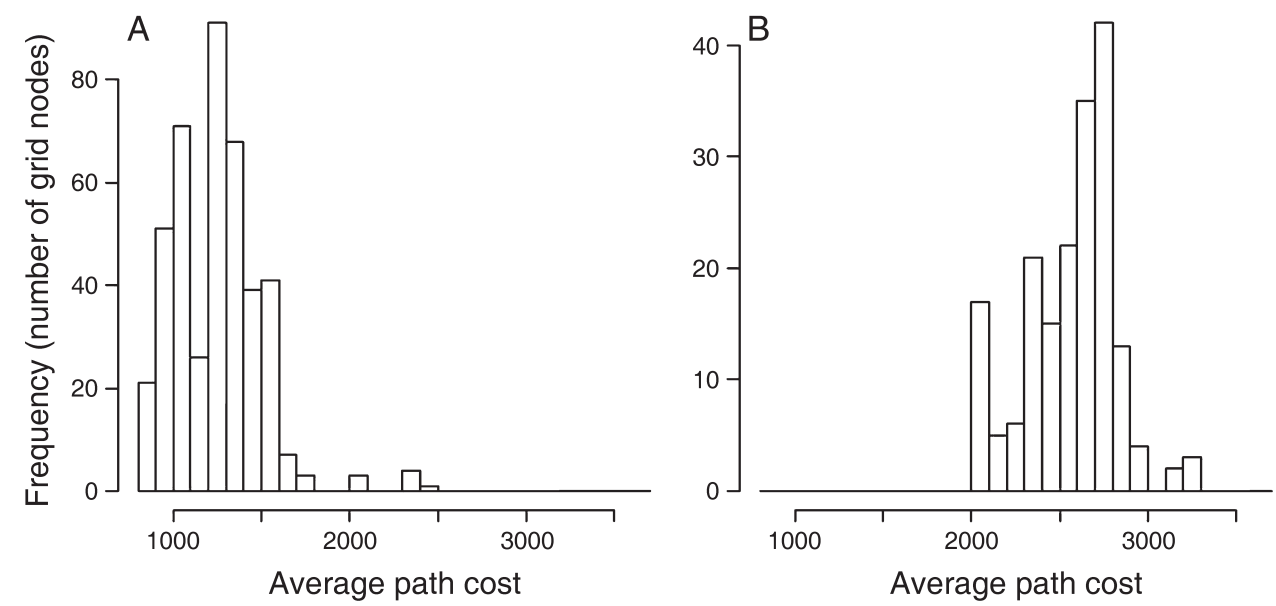

FIG. 12. Frequency distributions depicting the average path cost from each snow point to all other snow points comparing least-cost pathways based on (A) 15 May MODIS and (B) 29 May MODIS snow cover. Note that the $y$-axes are scaled differently for each date; see Fig. 9 for clarification of average path cost. 


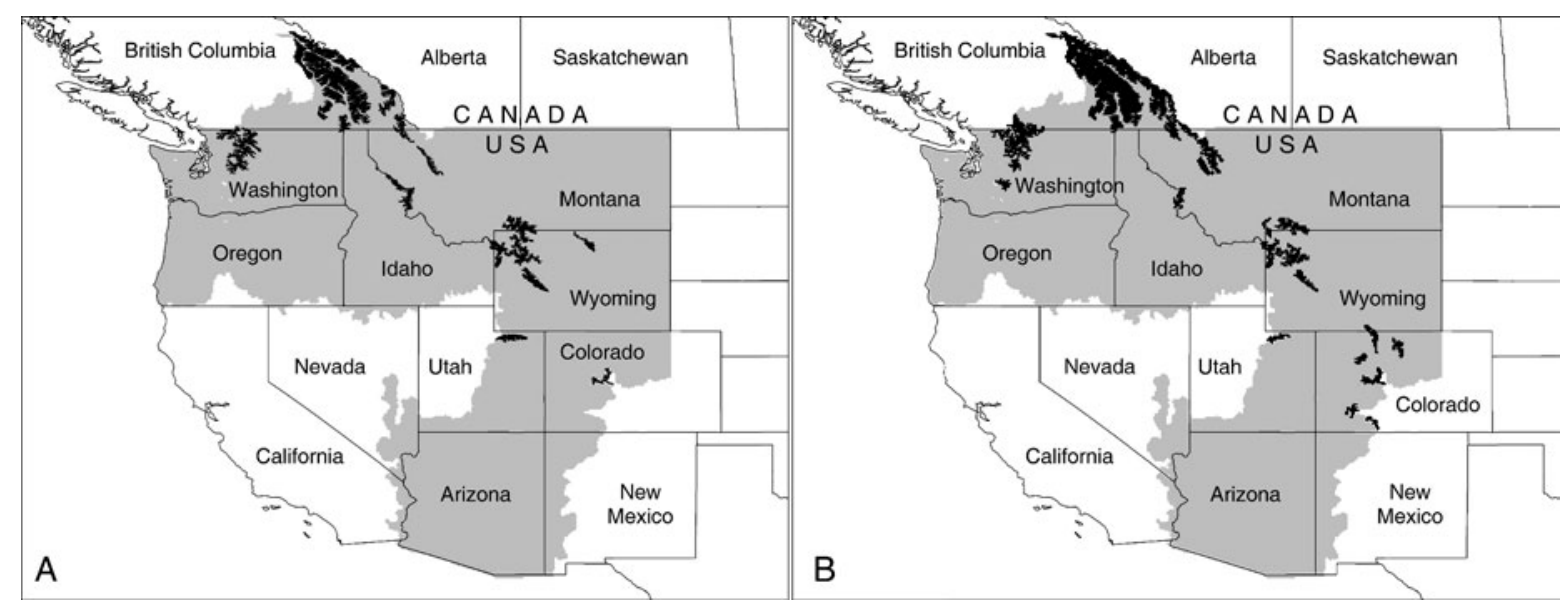

FIG. 13. Contiguous areas of persistent spring snow cover $>1000 \mathrm{~km}^{2}$ based on (A) MODIS snow cover shifted two weeks later in the year (29 May MODIS) and (B) the ensemble climate projection for the period 2070-2099 (Ensemble 2085). The study area is shown in gray, and snow cover is black.

states in the contiguous United States where wolverines currently occur (Washington, Idaho, Montana, and Wyoming) retain $75.3 \%$ of their spring snow cover based on Ensemble 2045. For Ensemble 2045, Montana and Idaho maintain some connected areas in the mid-21st century (Fig. 10), but many of the potential movement paths have much higher costs. Higher costs, coupled with decreased denning habitat, will likely lead to fewer successful wolverine dispersals. Therefore, as wolverine habitat shrinks during the 21st century, large contiguous areas of habitat where local extirpation is less likely to occur will become increasingly important for the conservation of wolverines in the western United States.

Continued warming trends may create many small and isolated populations that would be subject to high levels of demographic and genetic stochasticity. Wolverine populations are at risk from isolation (Krebs et al. 2004); their extirpation in Colorado and California likely resulted from a combination of high humancaused mortality and very low immigration rates (Aubry et al. 2007, Schwartz et al. 2007). Currently, many of the areas containing wolverines in the western United States support relatively small populations. For example, Squires et al. (2007) estimated that four mountain ranges in southwestern Montana collectively contained about 13 wolverines (12.8, 95\% CI $=9.9-15.7)$. Clearly, such population densities are too low for long-term persistence without connectivity to other populations. Schwartz et al.'s (2009) analysis assumed a welldistributed population of wolverines with all larger areas of habitat occupied. This is consistent with current understandings (see Aubry et al. 2007), but may not be in the future if decreased connectivity results in the loss of wolverine populations in many of the smaller mountain ranges. Meta-population theory predicts that decreased connectivity will shift the balance between colonization and extinction, leading to decreased patch occupancy (Levins 1969, 1970). Additionally, the predicted responses of meta-populations to reductions in occupied area are nonlinear and characterized by extinction thresholds (e.g., Lande 1987). Therefore, like the statistical downscaling of GCMs, the changes in connectivity predicted in our analyses should be considered conservative (see section on Limitations and caveats below); if most of the wolverine habitat was unoccupied, average movement costs would be much higher than indicated.

Although areas of wolverine habitat will likely be greatly reduced and isolated by the late 21 st century, relatively large islands of spring snow cover are predicted to persist. Contiguous areas of snow cover $>1000 \mathrm{~km}^{2}$ in size, which are large enough to support small breeding populations of wolverines and presumably large enough for short-term population persistence, are retained in both the Ensemble 2085 and 29 May MODIS projections. In particular, British Columbia contains extensive areas of spring snow cover that are connected to snow-covered areas in northwestern Montana. Additionally, large snow-covered areas exist in northern Washington, along the Montana-Idaho border, and in the Greater Yellowstone Area (Fig. 13). Colorado appears to provide habitat for wolverines in the late 21st century based on Ensemble 2085, but not in 29 May MODIS (Fig. 13).

Qualitatively, Ensemble 2085 and 29 May MODIS are similar because topographic patterns strongly constrain both projections. Both projections identify most of the same large areas of retained snow cover, which may provide potential refuges for wolverines: British Columbia, northern Washington, northwestern Montana, and the Greater Yellowstone Area (compare Fig. 4A with Fig. 4D). Ensemble 2085, however, predicts significantly more snow in Colorado than would be expected if the only process we modeled was accelerated spring snow 
melt. Colorado has virtually identical snow-covered areas in both the Historical Reconstruction and 15 May MODIS (Table 2). Although there is $10.2 \%$ less snow overall in 29 May MODIS compared to Ensemble 2085, there is $176 \%$ more snow-covered area in Colorado. This divergence does not indicate differences related to scale (see section on Limitations and caveats below). Rather, it is likely due to altered patterns of combined seasonal temperature and precipitation projected by the climate models; climate models are predicting more winter snow in this area by the end of the 21 st century. Conversely, the large degree of uncertainty associated with future snow conditions in Idaho (Fig. 6) may be due, at least in part, to the interaction between snow cover and spatial scale. In Idaho, spring snow cover is highly fragmented and follows narrow ridges in many areas (Fig. 2B). However, even in Idaho, where projections are most divergent, the overall results from comparing 29 May MODIS with Ensemble 2085 are similar: Idaho loses proportionately more of its snow cover than either Montana or Wyoming (Table 2). Additionally, even though connectivity modeling is sensitive to fine-grained changes in snow cover, the qualitative shifts in connectivity associated with losing Idaho as a population source are also very similar in both the Ensemble 2085 and MODIS 29 May projections (compare Figs. $8 \mathrm{C}$ and $11 \mathrm{~B})$.

\section{Limitations and caveats}

Throughout our analyses, we made many assumptions about constancy. We have assumed, for example, that observed relationships between the habitat use and movement patterns of wolverines and areas with persistent spring snow cover will remain constant if climatic conditions change. In downscaling climate models, we have assumed that small-scale climatic relationships will also remain constant. Any attempt to project climate patterns into the future will, by necessity, involve these kinds of assumptions. Thus, it is important to understand that the validity of our analyses will ultimately depend on the validity of such assumptions.

The downscaling approach used here assumes that relationships between local and regional climate will remain constant in the future. This assumption can lead to underestimations of local climate change. For example, using a regional climate model, Salathé et al. (2010) show that some montane areas in the PNW may warm faster than expected based on statistical downscaling due to decreased albedo associated with snow loss. These types of process-based feedbacks are not captured through statistical downscaling. However, Salathe et al. (2010) found that differences in regional projections were still dominated by the GCMs used to set boundary conditions, rather than by the scale of regional models used.

Additional areas of uncertainty are associated with possible changes in the nature of storm tracks, which may affect the future accumulation and distribution of snowpack (Salathé 2006), and therefore, the degree to which GCMs and their ensemble averages capture potential change. For these reasons, the use of ensemble means and the delta method for downscaling likely underestimate local climate changes that would impact wolverine habitat; changes in spring snow cover predicted by our analyses should be considered conservative.

Although wolverine distribution is closely tied to persistent spring snow cover (Copeland et al. 2010), we do not know how fine-scale changes in snow patterns within wolverine home ranges may affect population persistence. Wolverines den in the snow column itself or under snow-covered logs and boulders (Magoun and Copeland 1998, Landa et al. 1998); thus, we assume that decreasing spring snow cover within wolverine home ranges will reduce the availability of reproductive den sites. However, there are a variety of local factors that determine both where wolverines den and the quality of den sites. For example, reproductive dens are often associated with avalanche chutes (Lofroth and Krebs 2007), and wolverines of both sexes are associated with these features throughout the year (Krebs et al. 2007). Avalanche chutes provide both subnivean debris piles for denning (Lofroth and Krebs 2007) and food sources, including ungulate carrion in the winter and rodents in the summer (Krebs et al. 2007). Consequently, as the amount and timing of snowfall changes, associated changes in avalanche frequency and other small-scale phenomena could have significant effects on wolverine habitat quality.

Cross-walking the historical temperature and precipitation data to MODIS-based snow cover has a number of limitations. The first is that modeled snow depth (or SWE) is not an exact surrogate for persistent spring snow cover. However, these two metrics are highly correlated because the areas where snow cover persists into the spring are often those that support the deep snowpacks needed for wolverine denning. Arguably, snow depth may have a greater influence on wolverine denning than spring snow cover; Copeland et al. (2010) used snow cover because of the ability to obtain these data with precise spatial and temporal resolution. Thus, the MODIS snow cover is a proxy for the biological needs of the wolverine, but appears to be a very good one. Cross-walking to VIC-derived snow depth at much coarser resolution weakens this proxy association. In the modeled snow distributions, pixels are about $140 \times$ larger than they are in the $0.5-\mathrm{km}$ MODIS coverage. Given the complex topographic patterns in the western mountains of the contiguous United States, there are few areas where all 140 MODIS-scale pixels contained in a $1 / 16$ degree area will be persistently snow covered in midMay. Similarly, the average snow depth modeled across a 1/16-degree pixel will, in most cases, be an average between areas with deep persistent snow cover and areas that are generally bare. When statistically fitting the MODIS snow coverage to VIC-derived snow depth, the 
size and shape of snow-covered areas will therefore influence the local quality of the fit. Generally, in areas where snow is extensive and contiguous, the best fit will consistently lead to an increase in snow area with increased pixel size; most areas will be snow-covered and small, bare areas will be eliminated. Conversely, in areas where snow is highly fragmented or limited to linear areas along ridgelines, the best fit will produce larger pixels that are consistently classified as snow free. The excess (when compared to MODIS) snow cover in the Historical Reconstruction in areas such as northern Washington and British Columbia, and the lack of snow in areas such as Idaho, is at least partially due to these scaling issues and is unavoidable. Also, the time periods for the MODIS data and Historical Reconstruction are different. Data for the Historical Reconstruction were compiled for most of the 20th century, whereas MODIS data were limited to the first seven years of the $21 \mathrm{st}$ century (2000-2006).

Lastly, these analyses are constrained by the geographic extent of the river basins analyzed. States such as Oregon, which contain areas exterior to the three analyzed basins, likely contain more wolverine habitat, both currently and in the future, than is indicated in the figures and Table 2. Thus, there are probably areas in the contiguous United States that could provide future wolverine habitat, but are beyond the geographic scope of our analyses. Importantly, the potential contribution of the southern Sierra Nevada in California, which provided wolverine habitat historically (Aubry et al. 2007) and currently contains extensive areas of persistent spring snow cover (Copeland et al. 2010) was not considered here.

\section{Conclusions}

We expect that the geographic extent and connectivity of suitable wolverine habitat in western North America will decline with continued global warming. Under some scenarios, such as miroc 3.2, western North America heats up rapidly and snowpack is quickly eroded. However, the ensemble model does not behave like miroc 3.2; rather, it is much more similar to pcm 1 . If these scenarios are valid, then conservation efforts should focus on maintaining wolverine populations in the largest remaining areas of contiguous habitat and, to the extent possible, facilitating connectivity among habitat patches.

\section{ACKNOWLEDGMENTS}

We thank Eric Lutz for developing the gridded historical climate in the Upper Missouri Basin and Eric Salathé for assistance with GCM bias evaluation. We acknowledge the Program for Climate Model Diagnosis and Intercomparison (PCMDI) and the WCRP's Working Group on Coupled Modelling (WGCM) for their roles in making the WCRP CMIP3 multi-model data set available to us. Support for the PCMDI data set is provided by the Office of Science, U.S. Department of Energy. Support for the development of regionally consistent downscaled climate and hydrologic variables was provided by Regions 1 and 6 of the USDA
Forest Service and the U.S. Fish and Wildlife Service. Additionally we thank Patrick Gonzalez for exploratory spatial analyses of climate and snow. Finally, we are grateful for helpful reviews of two anonymous referees. This publication is partially funded by the Joint Institute for the Study of the Atmosphere and Ocean (JISAO) under NOAA Cooperative Agreement Numbers NA17RJ1232 and NA10OAR4320148, Contribution Number 1867.

\section{Literature Cited}

Armstrong, R. L., and M. J. Brodzik. 2005. Northern Hemisphere EASEGrid weekly snow cover and sea ice extent. Version 3. National Snow and Ice Data Center, Boulder, Colorado, USA.

Aubry, K. B., K. S. McKelvey, and J. P. Copeland. 2007. Distribution and broadscale habitat relations of the wolverine in the contiguous United States. Journal of Wildlife Management 71:2147-2158.

Copeland, J. P., et al. 2010. The bioclimatic envelope of the wolverine: Do climatic constraints limit their geographic distribution? Canadian Journal of Zoology 88:233-246.

Copeland, J. P., J. M. Peek, C. R. Groves, W. E. Melquist, K. S. McKelvey, G. W. McDaniel, C. D. Long, and C. E. Harris. 2007. Seasonal habitat associations of the wolverine in central Idaho. Journal of Wildlife Management 71:22012212.

Coulon, A., G. Guillot, J.-F. Couson, J. M. A. Angibault, S. Aulagnier, B. Cargnelutti, M. Galan, and A. J. M. Hewison. 2006. Genetic structure is influenced by landscape features: empirical evidence from a roe deer population. Molecular Ecology 15:1669-1679.

Cushman, S. A., K. S. McKelvey, J. Hayden, and M. K. Schwartz. 2006. Gene-flow in complex landscapes: testing multiple hypotheses with causal modeling. American Naturalist 168:486-499.

Cushman, S. A., K. S. McKelvey, and M. K. Schwartz. 2009. Use of empirically derived source-destination models to map regional conservation corridors. Conservation Biology 23:368-376.

Daly, C., W. P. Gibson, G. H. Taylor, G. L. Johnson, and P. A. Pasteris. 2002. A knowledge-based approach to the statistical mapping of climate. Climate Research 22:99-113.

Daly, C., M. Halbleib, J. I. Smith, W. P. Gibson, M. K. Doggett, G. H. Taylor, J. Curtis, and P. A. Pasteris. 2008. Physiographically-sensitive mapping of temperature and precipitation across the conterminous United States. International Journal of Climatology 28:2031-2064.

Daly, C., R. P. Neilson, and D. L. Phillips. 1994. A statisticaltopographic model for mapping climatological precipitation over mountainous terrain. Journal of Applied Meteorology 33:140-158.

Elsner, M. M., L. Cuo, N. Voisin, J. Deems, A. F. Hamlet, J. A. Vano, K. E. B. Mickelson, S. Y. Lee, and D. P. Lettenmaier. 2010. Implications of 21 st century climate change for the hydrology of Washington State. Climatic Change 102:225260.

Fowler, H. J., S. Blenkinsopa, and C. Tebaldi. 2007. Linking climate change modelling to impacts studies: recent advances in downscaling techniques for hydrological modelling. International Journal of Climatology 27:1547-1578.

Hall, D. K., G. A. Riggs, and V. V. Salomonson. 2006. MODIS/Terra snow cover daily L3 global $500 \mathrm{~m}$ grid. Version 4. National Snow and Ice Data Center, Boulder, Colorado, USA. 〈http://nsidc.org/data/modis/data.html〉

Hamlet, A. F., and D. P. Lettenmaier. 2005. Production of temporally consistent gridded precipitation and temperature fields for the continental United States. Journal of Hydrometeorology 6:330-336.

Hornocker, M. G., and H. S. Hash. 1981. Ecology of the wolverine in northwestern Montana. Canadian Journal of Zoology 59:1286-1301. 
IPCC. 2007. The physical science basis. Contribution of Working Group I to the Fourth Assessment Report of the Intergovernmental Panel on Climate Change (IPCC). S. Solomon, D. Qin, M. Manning, Z. Chen, M. Marquis, K. B. Averyt, M. Tignor, and H. L. Miller, editors. Cambridge University Press, Cambridge, UK.

Knowles, N., D. R. Cayan, and M. D. Dettinger. 2006. Trends in snowfall versus rainfall in the western United States. Journal of Climate 19:4545-4559.

Krebs, J., E. Lofroth, J. Copeland, V. Banci, H. Golden, A. Magoun, R. Mulders, and B. Shults. 2004. Synthesis of survival rates and causes of mortality in North American wolverines. Journal of Wildlife Management 68:493-502.

Krebs, J., E. C. Lofroth, and I. Parfitt. 2007. Multiscale habitat use by wolverines in British Columbia, Canada. Journal of Wildlife Management 71:2180-2192.

Landa, A., O. Strand, J. D. C. Linnell, and T. Skogland. 1998. Home range size and altitude selection for arctic foxes and wolverines in an alpine environment. Canadian Journal of Zoology 76:448-457.

Lande, R. 1987. Extinction thresholds in demographic models of territorial populations. American Naturalist 130:624-635.

Levins, R. 1969. The effects of random variation of different types on population growth. Proceedings of the National Academy of Sciences USA 62:1061-1065.

Levins, R. 1970. Extinction. Pages 77-107 in M. Gerstenhaber, editor. Some mathematical questions in biology. American Mathematical Society, Providence, Rhode Island, USA.

Liang, X., D. P. Lettenmaier, E. F. Wood, and S. J. Burges. 1994. A simple hydrologically based model of land surface water and energy fluxes for GSMs. Journal of Geophysical Research 99(D7):14415-14428.

Littell, J. S., G. Mauger, M. M. Elsner, E. Lutz, E. Salathé, and A. F. Hamlet. 2011. Regional climate and hydrologic change in the northern US Rockies and Pacific Northwest: internally consistent projections of future climate for resource management. Preliminary project report USFS JVA 09-JV11015600-039. Climate Impacts Group, University of Washington, College of the Environment, Seattle, Washington, USA. 〈http://cses.washington.edu/picea/USFS/pub/Littell_ etal_2010/Littel1_etal._2011_Regional_Climatic_And_Hydrologic_Change_USFS_USFWS_JVA_17Apr11.pdf $>$

Loarie, S. R., P. B. Duffy, H. Hamilton, G. P. Asner, C. B. Field, and D. D. Ackerly. 2009. The velocity of climate change. Nature 462:1052-1055.

Lofroth, E. C., and J. Krebs. 2007. The abundance and distribution of wolverines in British Columbia, Canada. Journal of Wildlife Management 71:2159-2169.

Macadam, I., A. J. Pitman, P. H. Whetton, and G. Abramowitz. 2010. Ranking climate models by performance using actual values and anomalies: Implications for climate change impact assessments. Geophysical Research Letters 37:L16704.

Magoun, A. J., and J. P. Copeland. 1998. Characteristics of wolverine reproductive den sites. Journal of Wildlife Management 62:1313-1320.

Manel, S., M. K. Schwartz, G. Luikart, and P. Taberlet. 2003. Landscape genetics: the combination of landscape ecology and population genetics. Trends in Ecology and Evolution 18:189-197.

Mantua, N., I. Tohver, and A. F. Hamlet. 2010. Impacts of climate change on key aspects of salmon habitat in Washington State. Climatic Change 102:187-223.

Meehl, G. A., C. Covey, T. Delworth, M. Latif, B. McAvaney, J. F. B. Mitchell, R. J. Stouffer, and K. E. Taylor. 2007. The WCRP CMIP3 multi-model dataset: a new era in climate change research. Bulletin of the American Meteorological Society 88:1383-1394.

Menne, M. J., C. N. Williams, Jr., and R. S. Vose. 2010. United States historical climatology network daily temperature. Precipitation and snow data. Carbon Dioxide Information Analysis Center, Oak Ridge National Laboratory, Oak Ridge, Tennessee, USA.

Menzel, A., et al. 2006. European phenological response to climate change matches the warming pattern. Global Change Biology 12:1969-1976.

Mote, P. W., A. F. Hamlet, M. P. Clark, and D. P. Lettenmaier. 2005. Declining mountain snowpack in western North America. Bulletin of the American Meteorological Society 86:39-49.

Mote, P. W., and E. P. Salathé. 2010. Future climate in the Pacific Northwest. Climatic Change 102:29-50.

Nakicenovic, N., et al. 2000. Special report on emissions scenarios. A special report of Working Group III of the Intergovernmental Panel on Climate Change. Cambridge University Press, New York, New York, USA.

Salathé, E. P., Jr. 2006. Influences of a shift in North Pacific storm tracks on western North American precipitation under global warming. Geophysical Research Letters 33:L19820.

Salathé, E. P., Jr., Y. Zhang, L. R. Leung, and Y. Qian. 2010. Regional climate model projections for the State of Washington. Climatic Change 102:51-75.

Schwartz, M. K., K. B. Aubry, K. S. McKelvey, K. L. Pilgrim, J. P. Copeland, J. R. Squires, R. M. Inman, S. M. Wisely, and L. F. Ruggiero. 2007. Inferring geographic isolation of wolverines in California using historical DNA. Journal of Wildlife Management 71:2170-2179.

Schwartz, M. K., J. P. Copeland, N. J. Anderson, J. R. Squires, R. M. Inman, K. S. McKelvey, K. L. Pilgrim, L. P. Waits, and S. A. Cushman. 2009. Wolverine gene flow across a narrow climatic niche. Ecology 90:3222-3232.

Squires, J. R., M. K. Schwartz, J. P. Copeland, L. F. Ruggiero, and T. J. Ulizio. 2007. Sources and patterns of wolverine mortality in western Montana. Journal of Wildlife Management 71:2213-2220.

Stewart, I. 2009. Changes in snowpack and snowmelt runoff for key mountain regions. Hydrological Processes 23:78-94.

USFWS [U.S. Fish and Wildlife Service]. 2010. Endangered and threatened wildlife and plants; 12-month finding on a petition to list the North American wolverine as endangered or threatened. Proposed Rule. Federal Register, 14 December 2010. Volume 75:78029-78061.

Wood, A. W., L. R. Leung, V. Sridhar, and D. P. Lettenmaier. 2004. Hydrologic implications of dynamical and statistical approaches to downscaling climate model outputs. Climatic Change 62:189-216. 